\title{
Changes of Activated Sludge Bacterial Population Caused by Addition of Extracts From Activated Sludge - Effects of Organic Loading and Incubation Time
}

\author{
Tao $\mathrm{SU}^{1}$, Hiroyasu SATOH${ }^{2}$ and Takashi $\mathrm{MINO}^{2}$ \\ ${ }^{1}$ JSCE Student Member, Dept. Socio-Cultural Environmental Studies, GSFS, The University of Tokyo \\ (5-1-5 Kashiwanoha, Kashiwa, Chiba, 277-8563, Japan) \\ E-mail:sutao@mw.k.u-tokyo.ac.jp \\ ${ }^{2}$ Member of JSCE, Assoc. Prof., Dept. Socio-Cultural Environmental Studies, GSFS, The University of Tokyo \\ E-mail: hiroyasu@k.u-tokyo.ac.jp \\ ${ }^{3}$ Member of JSCE, Professor, Dept. Socio-Cultural Environmental Studies, GSFS, The University of Tokyo \\ E-mail: mino@k.u-tokyo.ac.jp
}

\begin{abstract}
The effect of extract from activated sludge on bacterial population in activated sludge was studied especially focusing on the effect of organic loading and incubation time. A laboratory scale activated sludge reactor was operated, the extract was obtained from the sludge with ethanol as the extractant, and activated sludge was incubated with and without the addition of the extract. The incubation was performed with low $(0.5 \mathrm{kgCOD} / \mathrm{kgMLSS} \cdot \mathrm{d})$ and high $(2 \mathrm{kgCOD} / \mathrm{kgMLSS} \cdot \mathrm{d})$ organic loadings up to 96 hours on a microplate under aerobic condition. Samples were obtained at 24, 48 and 96 hours, and bacterial population in them were analyzed by both polymerase chain reaction (PCR) with restriction fragment length polymorphism (RFLP) and reverse transcription PCR/RFLP. Clear difference in bacterial population was observed within 24 hours of incubation even when low organic loading was applied and increase of biomass amount was thought to be only around $25 \%$.
\end{abstract}

Key Words : bacterial population changes, activated sludge, ethanol-soluble extract, microplate, RT-PCR/RFLP, PCR/RFLP

\section{Introduction}

Bacterial population in activated sludge is known to affect the performance of wastewater treatment. Different studies have also been conducted to understand the effects of different factors on activated sludge bacterial populations, but they mostly focused environmental factors which are given to bacterial ecosystems such as $\mathrm{pH}^{1)}$, dissolved oxygen ${ }^{2)}$, and temperature $^{3)}$. Recently, bacteriophages are also attracting interest of researchers as they are suspected to affect bacterial population ${ }^{4), 5)}$.

Chemicals produced by bacteria are also suspected to affect bacterial population in activated sludge, but studies are very limited. For example, Valle et al. incubated activated sludge with and without the addition of $\mathrm{N}$-acyl homoserine lactones (AHLs) ${ }^{6}$, which are known as signal compounds in bacterial communication, and found that the existence of $2 \mu \mathrm{M}$ of AHLs affected bacterial population. Ichihashi et al. conducted batch experiments by mixing two activated sludges, one with higher activity of enhanced biological phosphorus removal (EBPR) and the other with deteriorated EBPR, at different mixing ratios. They reported that the EBPR-related metabolisms were not linear to the mixing ratios and attributed the possible cause to chemicals that affect bacterial metabolisms ${ }^{7)}$. Satoh et al. $^{8)}$ obtained extract from activated sludge with ethanol as the extractant, and incubated activated sludge with extract for 4 days and found bacterial population in the activated sludge incubated with extract was significantly different from that incubated without extract. Interactions of bacteria mediated by chemicals requires to be studied more.

While chemical components have been reported to affect bacterial population, information available is still limited. For example, the time required for the 
chemicals to cause bacterial population change is not clear. Valle et $a l^{6}{ }^{6}$ observed bacterial population change only after 10 days or more of incubation, while Satoh et $a{ }^{8}{ }^{8}$ observed one after 4 days of incubation. It is not clear if population is changed within shorter period of time. The organic loading rate during incubation should also be of importance: the higher the organic loading rate, the more the growth of biomass would be, and it would be easier to detect change of bacterial population. Thus, to examine if a chemical of interest cause bacterial population change or not, a higher organic loading rate would be beneficial to shorten the time of incubation to detect bacterial population change. But changing organic loading rate from the original condition where the bacterial population has been established may bring about side effects.

In the present study, the authors investigated bacterial population changes of activated sludge with different organic loading and time with and without the addition of extract from activated sludge. Incubation was performed on a microplate to perform triplicate experiments on each condition. Changes of bacterial population was monitored by polymerase chain reaction (PCR) in combination with restriction fragment length polymorphism (RFLP) and by reverse-transcription- (RT-) PCR/RFLP. While PCR/RFLP was performed to grasp bacterial population including less active bacteria, RT-PCR/RFLP was performed to monitor active bacterial population.

\section{MATERIAIS AND METHODS}

\section{(1) Outline of the experiments}

The authors operated a laboratory scale sequencing batch activated sludge reactor (SBR). The extract used in the present study was obtained from activated sludge mixed liquor sampled on day $137^{\text {th }}$. On day $148^{\text {th }}$, again activated sludge sample was obtained from the SBR, and was incubated on a microplate with and without the addition of extract obtained from the sludge on day $137^{\text {th }}$. Bacterial populations in the activated sludge incubated on the microplate were analyzed by PCR/RFLP and by RT-PCR/RFLP. The operation of the SBR is described in (2), the protocol to prepare the extract is described in (3), incubation on the microplate is described in (4), monitoring of bacterial growth is describe in (5) the methods of the bacterial population analysis and the statistical analyses are described in (6) and (7).

While activates sludge samples for the extraction of chemical components and for incubation microplate were obtained at different timings other than days $137^{\text {th }}$ and $148^{\text {th }}$, in this report, the result for this combination is reported, because bacterial population change was the most significant with this combination.

\section{(2) SBR operation}

The SBR was operated with synthetic wastewater containing acetate, propionate, peptone and yeast extract as the organic matters as the influent. The composition of the stock feed was as follows: $\mathrm{CH}_{3} \mathrm{COONa} \cdot 3 \mathrm{H}_{2} \mathrm{O} \quad(11.3 \mathrm{~g} / \mathrm{L}), \quad \mathrm{CH}_{3} \mathrm{CH}_{2} \mathrm{COONa}$ $(5.36 \mathrm{~g} / \mathrm{L})$, peptone $(10 \mathrm{~g} / \mathrm{L})$, yeast extract $(2 \mathrm{~g} / \mathrm{L}), \mathrm{KCl}$ $(4.2 \mathrm{~g} / \mathrm{L}), \quad \mathrm{CaCl}_{2} \cdot 2 \mathrm{H}_{2} \mathrm{O} \quad(1.32 \mathrm{~g} / \mathrm{L}), \quad \mathrm{MgSO}_{4} \cdot 7 \mathrm{H}_{2} \mathrm{O}$ $(11 \mathrm{~g} / \mathrm{L}), \mathrm{K}_{2} \mathrm{HPO}_{4}(3.6 \mathrm{~g} / \mathrm{L}), \mathrm{FeCl}_{3} \cdot 6 \mathrm{H}_{2} \mathrm{O}(113.6 \mathrm{mg} / \mathrm{L})$, $\mathrm{H}_{3} \mathrm{BO}_{3}(11.36 \mathrm{mg} / \mathrm{L}), \mathrm{CuSO}_{4} \cdot 5 \mathrm{H}_{2} \mathrm{O}(2.272 \mathrm{mg} / \mathrm{L}), \mathrm{KI}$ $(13.6 \mathrm{mg} / \mathrm{L}), \quad \mathrm{MnCl}_{2} \cdot 4 \mathrm{H}_{2} \mathrm{O} \quad(9.09 \mathrm{mg} / \mathrm{L})$, $\mathrm{Na}_{2} \mathrm{MoO}_{4} \cdot 2 \mathrm{H}_{2} \mathrm{O} \quad(4.546 \mathrm{mg} / \mathrm{L}), \quad \mathrm{ZnSO}_{4} \cdot 7 \mathrm{H}_{2} \mathrm{O}$ $(9.09 \mathrm{mg} / \mathrm{L}), \quad \mathrm{CoCl} \cdot 6 \mathrm{H}_{2} \mathrm{O} \quad(11.36 \mathrm{mg} / \mathrm{L}), \quad$ EDTA $(757.6 \mathrm{mg} / \mathrm{L})$. The stock feed was diluted by 110 times with tap water, then supplied to the SBR. The chemical oxygen demand (COD) of the influent was around $400 \mathrm{mg} / \mathrm{L}$, and the organic loading rate was $0.37 \mathrm{kgCOD} /(\mathrm{kgMLSS} \cdot \mathrm{d})$. The seed activated sludge was obtained from a full-scale wastewater treatment plant in Chiba Prefecture, Japan. The total volume of the reactor was $10 \mathrm{~L}$, and was operated with 4-hours cycles including $1 \mathrm{~h}$ of anaerobic phase and $2 \mathrm{~h}$ aerobic phase. The hydraulic retention time (HRT) was $8 \mathrm{~h}$, and the sludge retention time (SRT) was kept at 4 days.

\section{(3) Preparation of extract from the activated sludge}

On day $137^{\text {th }}, 100 \mathrm{~mL}$ of the activated sludge with mixed liquor suspended solids (MLSS) concentration of $3260 \mathrm{mg} / \mathrm{L}$ was taken from the SBR at the end of the aerobic phase, centrifuged at $3500 \mathrm{rpm}$ for $5 \mathrm{~min}$, the supernatant was decanted and the sludge pellet was washed with reverse osmosis (RO) water twice and water-liquid was discarded, the sludge was further freeze-dried. Then $100 \mathrm{~mL}$ ethanol was added, the sludge was resuspended, and incubated at $15^{\circ} \mathrm{C}$ for 24 hours on a rotary shaker at $300 \mathrm{rpm}$. Then the mixture was centrifugation at 3500 rpm for $5 \mathrm{~min}$ and the ethanol phase was recovered. The ethanol extract was filtered through $0.2 \mu \mathrm{m}$ to remove residual solids, and preserved in $-20^{\circ} \mathrm{C}$ until use.

\section{(4) Microplate incubation}

A 96-well microplate (Tissue Culture Test Plates Model 92096, Techno Plastic Products AG, Switzerland) was employed for the microplate incubation experiment. The wells on the microplate were designed to be used as illustrated in Fig. 1. The wells in rows $\mathrm{F}, \mathrm{G}$ and $\mathrm{H}$ were added with $300 \mu \mathrm{L}$ ethanol extract and the wells in rows $\mathrm{A}, \mathrm{B}$ and $\mathrm{C}$ were added with $300 \mu \mathrm{L}$ ethanol as the control. Then ethanol in the wells were allowed to completely dry in an in- 
cubator at $15^{\circ} \mathrm{C}$ for $24 \mathrm{~h}$ with rotary mixing at $50 \mathrm{rpm}$.

On day $148^{\text {th }}, 25 \mathrm{~mL}$ of activated sludge with MLSS of $1440 \mathrm{mg} / \mathrm{L}$ was obtained from the SBR. The activated sludge was gently sonified, added with $25 \mathrm{~mL}$ ultrapure water (Milli-Q Synthesis, Millipore, USA), and coarse solids were removed by settling for 15 minutes. The supernatant was recovered, and was further diluted with ultrapure water to make the MLSS concentration around $300 \mathrm{mg} / \mathrm{L}$. Then $290 \mu \mathrm{L}$ diluted activated sludge was loaded onto each of the wells of the microplate.

The wells in columns 3, 7 and 11 were used for incubation with high organic loading at 2 $\mathrm{kgCOD} /(\mathrm{kgMLSS} \cdot \mathrm{d})$, while those in columns 2,6 and 10 were used for incubation with low organic loading at $0.5 \mathrm{kgCOD} /(\mathrm{kgMLSS} \cdot \mathrm{d})$, and those in columns 1,5 and 9 were used for incubation without organic substrates. That is, to the wells with high and low organic loadings, $7.2 \mu \mathrm{L}$ and $1.8 \mu \mathrm{L}$ respectively of the stock feed solution as mentioned in "(2) SBR operation" was loaded every 24 hours. The volume of liquid in each well was made up to $300 \mu \mathrm{L}$ by adding ultrapure water.

The microplate was incubated for 96 hours under mixing at $1500 \mathrm{rpm}$ on a micro-plate shaker Microplate Genie (Scientific Industries, USA). The sludge mixture were recovered after 24 hours (columns 1, 2 and 3), 48 hours (columns 5, 6 and 7) or 96 hours (columns 9, 10 and 11) of incubation. During incubation, the wells were sealed with a gas permeable seal (Abgene AB-0718, Thermo Fisher Scientific Inc., USA) except during feeding and monitoring of optical density.

For each condition, incubation was performed in triplicate by assigning three wells. for example, wells F2, G2 and H2 were used for 24 hours incubation with low organic loading with extract addition.

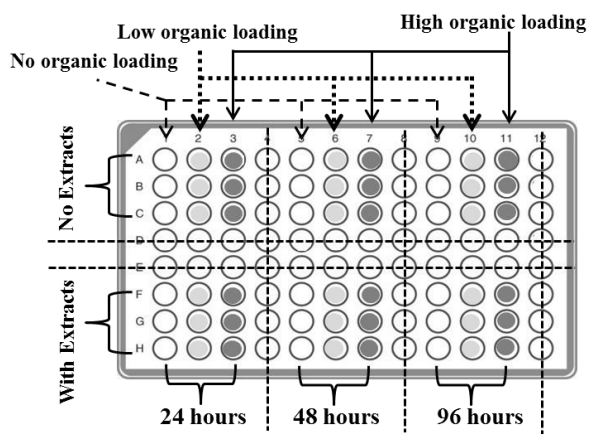

Fig.1 Incubation strategy of activated sludge on micropale.

\section{(5) Optical density measurement}

The optical density at $600 \mathrm{~nm}$ of the activated sludge in each of the microplate wells were moni- tored every 24 hours by a microplate reader SH-1000Lab (Hitachi High-technologies Cor., Japan) as an indicator of the growth of bacteria in each well. The outliers were identified the Grubb's test for one outliner using the package "outliers" " with $\mathrm{R}^{10)}$.

\section{(6) Bacterial population analysis}

Each of the activated sludge samples recovered from the microplate wells, $300 \mu \mathrm{L}$ each, was transferred to a $1.5 \mathrm{~mL}$ tube, added with $300 \mu \mathrm{L}$ ethanol, sonicated (AD250, Branson, USA) at an amplitude of $30 \%(7 \mathrm{~W})$ for $30 \mathrm{~s}$, diluted 10 times with autoclaved ultrapure water, and used as the template for PCR and RT-PCR reaction ${ }^{11)}$.

\section{a) PCR}

TaKaRa ExTaq Hot Start Version (Takara Cor., Japan) was used for PCR amplification with $27 \mathrm{f}$ (5'AGA GTT TGA TCM TGG CTC AG -3') and 519r (5'- GWA TTA CCG CGG CKG CTG-3') primers $^{12)}$. The composition of the reaction mixture was as follows: $2 \mu \mathrm{L} 10 \times$ buffer, $1.6 \mu \mathrm{L}$ dNTP Mixture (2.5mM each), $0.4 \mu \mathrm{L} 27 \mathrm{f}$ primer $(10 \mathrm{pmol} / \mu \mathrm{L}), 0.4$ $\mu \mathrm{L} 519 \mathrm{r}$ primer $(10 \mathrm{pmol} / \mu \mathrm{L}), 0.1 \mu \mathrm{L}$ TaKaRa Ex TaqHS ( 5 units $/ \mu \mathrm{L}$ ), $2 \mu \mathrm{L}$ template, and $13.5 \mu \mathrm{L}$ of autoclaved ultrapure water. The PCR reaction was performed by a thermal cycler Dice (TaKaRa, Japan) with the thermal program as follows: $94^{\circ} \mathrm{C}$ for 10 $\min , 30$ cycles of $94^{\circ} \mathrm{C}$ for $30 \mathrm{~s}, 55.3^{\circ} \mathrm{C}$ for $30 \mathrm{~s}, 72^{\circ} \mathrm{C}$ for $30 \mathrm{~s}$, and a final extension step of $72^{\circ} \mathrm{C}$ for 10 min.

\section{b) RT-PCR}

PrimeScript One Step PCR Kit Version 2 (Takara Cor., Japan) was used for RT-PCR with the primers of $27 \mathrm{f}$ and $519 \mathrm{r}$. The composition of the reaction mixture was as follows: $5 \mu \mathrm{L} 2 \times$ buffer, $0.4 \mu \mathrm{L}$ forward primer $(10 \mathrm{pmol} / \mu \mathrm{L}), 0.4 \mu \mathrm{L}$ reverse primer $(10$ $\mathrm{pmol} / \mu \mathrm{L}), 0.2 \mu \mathrm{L}$ RNasin (Promega, USA), $0.4 \mu \mathrm{L}$ prime script enzyme mixture, $1 \mu \mathrm{L}$ template, and 2.6 $\mu \mathrm{L}$ RNase-free water. The RT-PCR reaction was performed by a thermal cycler Dice (TaKaRa, Japan) with the thermal program as follows: $50^{\circ} \mathrm{C}$ for 30 $\min , 94^{\circ} \mathrm{C}$ for $2 \mathrm{~min}, 20$ cycles of $94^{\circ} \mathrm{C}$ for $30 \mathrm{~s}$, $55.3^{\circ} \mathrm{C}$ for $30 \mathrm{~s}, 72^{\circ} \mathrm{C}$ for $30 \mathrm{~s}$, and a final extension step of $72^{\circ} \mathrm{C}$ for $10 \mathrm{~min}$.

\section{c) RFLP}

After PCR and RT-PCR, the product concentrations were checked by using PicoGreen dsDNA Quantification Kit (Invitrogen, USA). The PCR and RT-PCR products from each sample was diluted to around to $25 \mathrm{ng} / \mu \mathrm{L}$, and digested by the restriction enzyme HhaI (TaKaRa Cor., Japan) at $37^{\circ} \mathrm{C}$ for three hours. The composition of the reaction mixture was as follow: $5 \mu \mathrm{L}$ PCR or RT-PCR product $(25 \mathrm{ng} / \mu \mathrm{L})$, $1 \mu \mathrm{L} 10 \times$ Buffer, $0.3 \mu \mathrm{L} H$ HaI Enzyme $(10 \mathrm{U} / \mu \mathrm{L})$, and $3.7 \mu \mathrm{L}$ of autoclaved ultrapure water. The restriction fragments were analyzed by capillary gel electro- 
phoresis by Bioanalyzer 2100 (Agilent Technologies, USA).

\section{(7) Principal Component Analysis (PCA)}

Bands for all RFLP analyses were detected by the Agilent 2100 Expert software (Version B.02.08, Agilent Technologies, USA). Intensity threshold was adjusted so that most of visible bands were detected. The area intensities of the bands were standardized against the total band area intensities in each sample, minor peaks occupying less than $1 \%$ of total area intensities were omitted, and bands at the same positions were carefully assigned manually. The data was further analyzed by MarkerView (Version 2.0, AB Sciex Pte. Ltd., USA) for PCA analysis with the Pareto scaling method after logarithmic conversion.

\section{RESULTS}

The authors are reporting herewith results obtained with the extract obtained from day $137^{\text {th }}$ SBR activated sludge. The authors tried similar experiments (obtaining extract from activate sludge, and several days later start incubation with and without extract addition on a microplate) around once a month before day $137^{\text {th }}$, but bacterial population change was not significant.

\section{(1) Growth of activated sludge in the wells}

The optical densities of activated sludge in each of the wells fed with substrate increased as incubation proceeded, as shown in Fig. 2. Outlier plots in gray resulted most probably from the inhomogeneous growth of bacteria such as in bigger flocs and growth attached to the wall. The optical density was around 0.15 initially, and it linearly increased to around 0.3 and 0.7 in the wells with low and high organic loadings respectively after 96 hours of incubation. The addition or omission of the extract did not cause significant change in the increase of the optical densities.

\section{(2) Comparison of bacterial population of acti- vated sludge after incubation}

Bacterial population in the microplate wells were analyzed by PCR/RFLP and RT-PCR/RFLP, and the results were as shown in Fig. 3. Three wells incubated under the identical conditions gave similar band patterns with each other. When band patterns are compared between with and without extract addition, significant difference were observed.

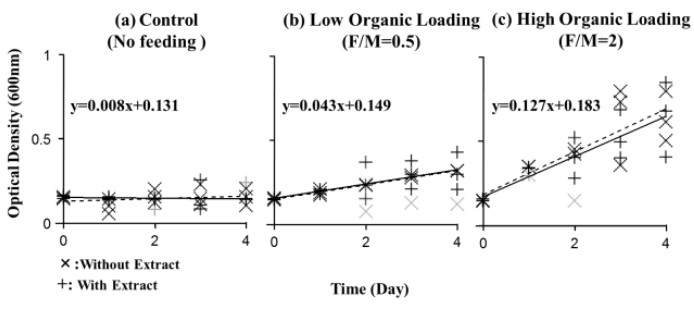

Fig.2 Optical densities of activated sludge in the microplate wells. The plots in gray are those that were rejected by the Grubb's test. The solid and broken lines are the regression lines for the accepted plots in each condition.

To more clearly compare the band patterns, the results of the PCR/RFLP analyses were further processed by PCA. As Fig. 4 shows, the band patterns were divided into three groups as indicated by the dotted circles. The lower left group and the higher left group were for the samples with high organic loading and low organic loading without extract addition, respectively. On the other hand, the middle right group was the samples with extract addition with both high and low organic loadings. The original activated sludge sample was in the higher left group suggesting that bacterial population in the control did not change so much and population structure resulted from the organic loading. The plots for the higher loading without extract addition at 24 hours incubations were located a bit closer to the group with extract addition.

In Fig. 5, the electropherograms of PCR/RFLP results for low organic loading conditions are compared. On the left side of Fig. 5, electropherograms for the samples incubated without extract are shown in time series: while minor differences can be observed, such as that bands (or peaks) a and c became weaker and band $f$ stronger as incubation proceeded, the band patterns were similar with each other. On the right side, PCR/RFLP results for the samples incubated with the addition of extract are shown. When compared with the band pattern for the sample before incubation, apparent differences can be identified: band $b$ became stronger, band e emerged, band $\mathrm{g}$ emerged during the initial 24 hours and disappeared afterwards, band d emerged toward the end of incubation, and band $\mathrm{f}$ disappeared during the initial 24 hours.

The results of the PCR/RFLP and RT-PCR/RFLP were compared by PCA. As shown in Fig. 6 . The plots were grouped into three: the RT-PCR/RFLP results without extract addition (middle right), the PCR/RFLP results without extract addition (lower left) and the RT-PCR/RFLP and PCR/RFLP results with extract addition (higher left). That is, PCR/RFLP and RT-PCR/RFLP gave similar results 
when extract was added, but gave significantly different results when extract was not added. The results suggested some groups of bacterial could be enhanced to become dominated in the community due to the extract addition.

\section{DISCUSSION}

As can be seen in Figs. 3 and 4, the addition of extract from activated sludge caused significant change in the RFLP band patterns. The changes in RFLP band patterns are thought to reflect change in bacterial population. While Valle et al. ${ }^{6}$ observed bacterial population change caused by the addition of AHL only after 10 days or more of incubation, and Satoh et al. ${ }^{8)}$ observed bacterial population change by the addition of activated sludge extract only after 4 days of incubation, in the present study, population change was observed only after 24 hours of incubation. Yet, response time may be much shorter, and experiments with shorter incubation time is worth to be done.

As can be seen in Fig. 4, when low organic loading of $0.5 \mathrm{kgCOD} /(\mathrm{kgMLSS} \cdot \mathrm{d})$ was applied, while change in bacterial population was small even after 96 hours, the addition of extract caused significant change in bacterial population only within 24 hours of incubation. On the other hand, when high organic loading of $2 \mathrm{kgCOD} /(\mathrm{kgMLSS} \cdot \mathrm{d})$ was applied, bacterial population changed significantly from the original population within 24 hours. Yet, the population structure between extract-added and non-added samples were significantly different. And the plot of samples incubated with the extract were plotted close with each other regardless of the organic loading rate and incubation time.

It is interesting that the 24 hours incubation samples without extract were plotted relatively closer to the plots for the samples incubated with extract. It is worth to compare bacterial population in these two groups of samples ( $24 \mathrm{hr}$ incubation with high loading without extract, and all incubation with extract) in more detail. If bacterial population in these two groups are really similar, it would mean that high organic loading affected bacterial population in the same direction as the extract did. A possible explanation would be that chemicals in extracts may stimulate bacterial species that are good at living under higher organic loading rate.

Significant bacterial population change was observed even with relatively small increase of bacterial population. If no bacteria die during incubation but only limited group of bacteria preferentially grow, change of bacterial population cannot easily be detected when growth is small. Yet, in the present study, the addition of extract was found to cause significant change in bacterial population even with $25 \%$ or so of increase (Fig. 2) in biomass after 24 hours of incubation with low organic loading of 0.5 $\mathrm{kgCOD} /(\mathrm{kgMLSS} \cdot \mathrm{d})$. While as shown in Fig. 5, the addition of the extract not only caused the emergence of new bands or intensified some of the bands, but also caused disappearance of some bands (such as band f) within 24 hours of incubation.

It is of interest why bacterial group corresponding to band $\mathrm{f}$ disappeared. When a cell dies and ceases metabolisms, its DNA will not immediately disappear, or rather, it can remain a longer time. A good example is the use of DNA in archaeology. The disappearance of DNA as found above is quite unusual, and it should be worth to clarify the mechanisms behind. The bacterial species that disappeared with their DNA not only lost their metabolic activities, but looks like they were "eaten and digested" by somebody.

The organic loading rate of 0.5 $\mathrm{kgCOD} /(\mathrm{kgMLSS} \cdot \mathrm{d})$ was close to that to the SBR from which the activated sludge was originally taken. The result obtained here suggests that bacterial population in the SBR can be affected even within a day by chemicals generated by microorganisms in activated sludge. 

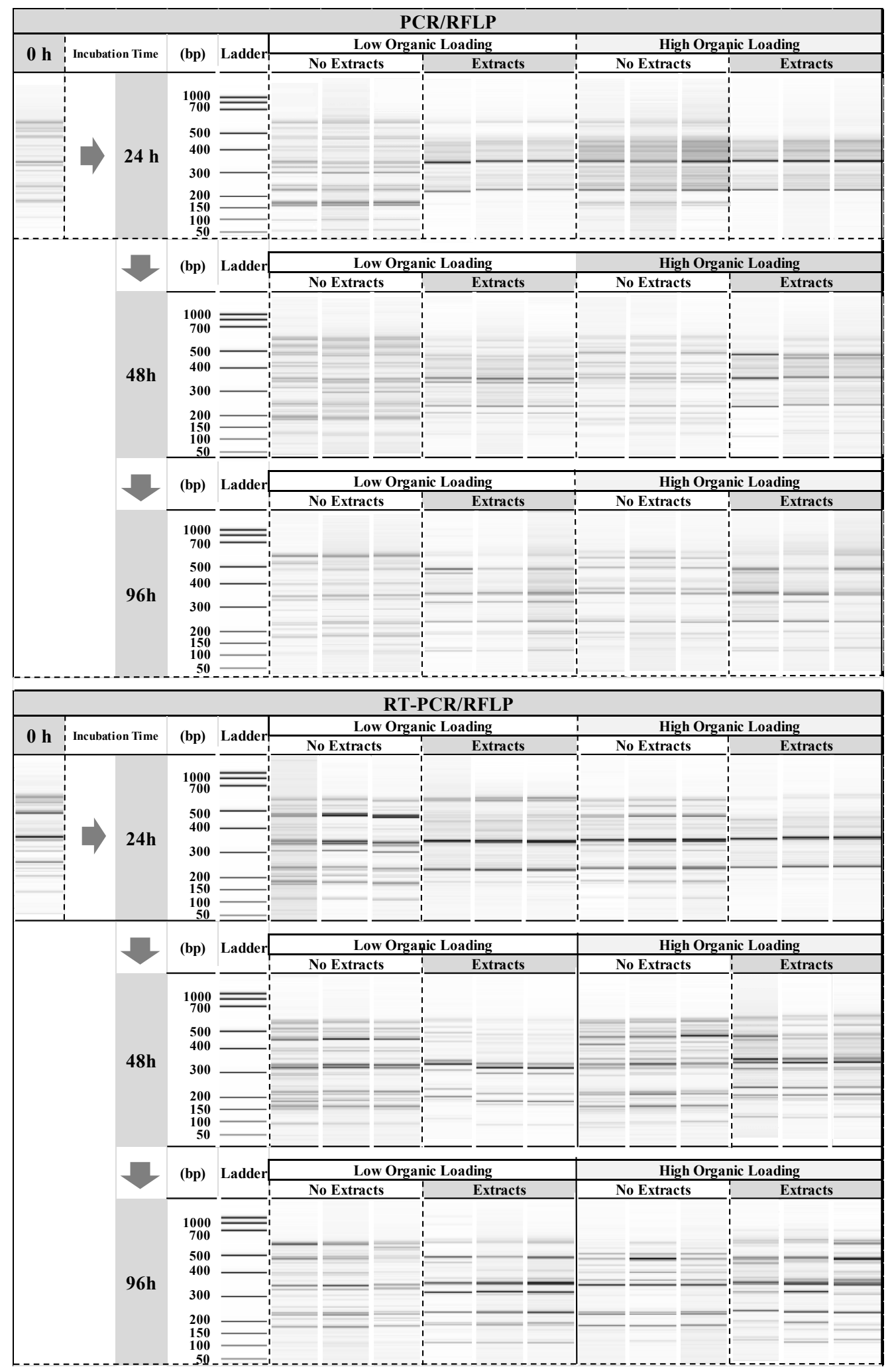

Fig.3 PCR/RFLP and RT-PCR/RFLP results for the original sample and for the samples after incubation on microplate wells with and without extract addition with high and low organic loading conditions. 


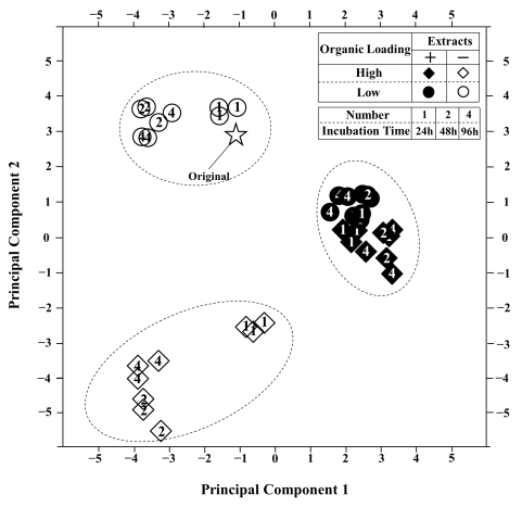

Fig.4 Comparison of PCR/RFLP band patterns by PCA. The contributions of the first and second principal components were $22.0 \%$ and $20.9 \%$, respectively.

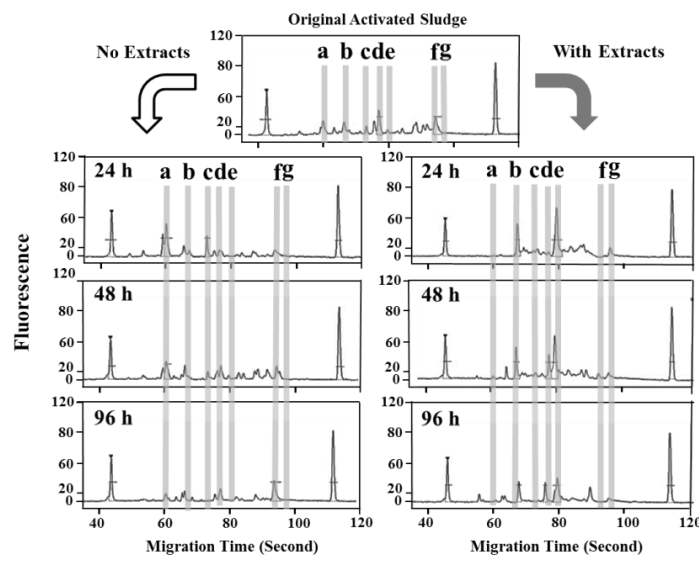

Fig.5 The PCR/RFLP results for the samples with and without extract addition under low organic loading condition (samples in wells B2, B6, B10, G2, G6, G10 shown in Fig.1 as representative).

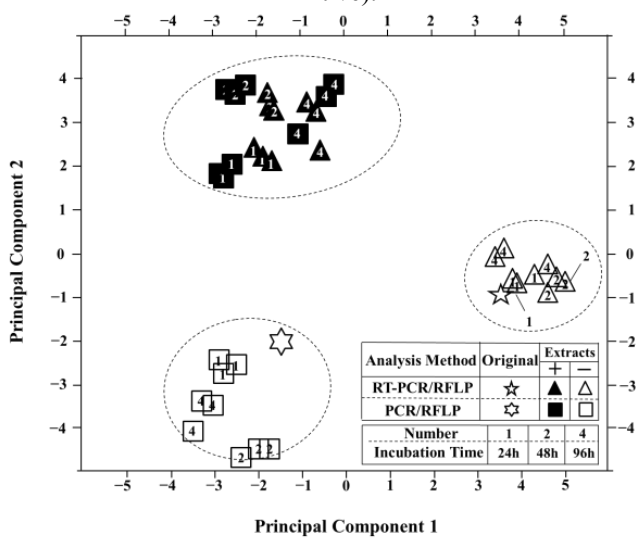

Fig.6 Comparison of the PCR/RFLP and RT-PCR/RFLP for low loading incubation condition. The contributions of the first and second principal components were $21.6 \%$ and $17.1 \%$, respectively.
In the present study, bacterial population was analyzed not only by PCR/RFLP but also by RT-PCR/RFLP. In general, RT-PCR targeting $16 \mathrm{~S}$ ribosome RNA is thought to reflect the active fraction of bacterial population in environmental samples $^{13), 14}$. On the other hand, PCR can amplify DNA sequences not only in live cells but also in dead cells ${ }^{14)}$. The difference of RT-PCR-based profiling targeting ribosomal RNA and PCR-based profiling targeting ribosomal RNA gene has been utilized on study of the soil bacterial community structure ${ }^{15), 16)}$. As shown in Fig. 6, PCR/RFLP and RT-PCR/RFLP results were clearly distinguished when incubated without the addition of extract. On the other hand, when extract was added, PCR/RFLP and RT-PCR/RFLP results were plotted close with each other. This observation, the plots for PCR/RFLP and RT-PCR/RFLP were close with each other when extract was added but were separated when extract was not added, is of interest, but difficult to give explanation for it. Maybe when extract was not added bacteria with different growth activities were anyhow competing with each other, and when extract was added, only selected group of species became similarly active.

As the authors mentioned at the beginning of the results part, it was only with extract obtained from day $137^{\text {th }}$ SBR activated sludge that gave significant bacterial population change. Thus, the authors admit that the results reported here are rather preliminary, and the observation here reported requires more confirmation in terms of consistency during the operation of an activated sludge reactor from which to obtain extract. Yet, interactions between organisms are often not stable, such as the interactions between human beings and pathogenic microorganisms, it is highly possible that the bacterial interactions through chemical molecules also highly fluctuate in time. Ichihashi et al. ${ }^{7}$ and Satoh et al. ${ }^{8)}$ also reported the fluctuation of chemical-mediated interactions in time.

\section{CONCLUDING REMARKS}

In this study, the incubation time and organic loading were investigated on the bacterial population changes of activated sludge by addition of extracts.

When activated sludge was incubated without extract addition and when low organic loading close to the original SBR was applied, similar bacterial population to that of original activated sludge was maintained. But the addition of extract caused change in bacterial population only within 24 hours when increase of biomass was only around $25 \%$.

The addition of extract resulted in not only in- 
crease but also decrease of some of bacterial species. The species that decreased their abundances disappeared with their DNA.

While bacterial and bacterial interactions through chemicals are of interest, the lack of methodologies is hindering progress in research. The authors hope that the findings here on time scale of interactions and on the effect of organic loading rate would be of use for further studies.

\section{ACKNOWLEDGMENTS}

This work was supported by JSPS KAKENHI Grant Number 22246069.

\section{REFERENCES}

1) Filipe, C. D. M., Daigger, G. T., Grady, C. P. L. : pH as a key factor in the competition between glycogen-accumulating organisms and phosphorus-accumulating organisms, Water Environ. Res., Vol. 73, pp. 223-232, 2001.

2) Lemaire, R., Meyer, R., Taske, A., Crocetti, G.R., Keller, J., Yuan, Z. G. : Identifying causes for $\mathrm{N}_{2} \mathrm{O}$ accumulation in a lab-scale sequencing batch reactor performing simultaneous nitrification, denitrification and phosphorus removal, $J$. Biotechnol, Vol. 122, pp. 62-72, 2006.

3) Erdal, U. G., Erdal, Z.K., Randall, C.W. : The competition between PAOs (phosphorus accumulating organisms) and GAOs (glycogen accumulating organisms) in EBPR (enhanced biological phosphorus removal) systems at different temperatures and the effects on system performance, Water Sci. Technol., Vol. 47, pp. 1-8, 2003.

4) Lee, S. H., Otawa, K., Onuki, M., Satoh, H., Mino, T. : Dynamics behavior of phage-host system related to $\mathrm{Mi}$ crolunatus phosphovorus in activated sludge with host inoculation, J. Microbiol. Biotechnol., Vol. 16, pp. 1518-1522. 2006.

5) Lee, S. H., Otawa, K., Onuki, M., Satoh, H., Mino, T. : Population dynamics of phage-host system of Microlunatus phosphovorus indigenous in activated sludge, J. Microbiol. Biotechnol., Vol. 17, pp. 1704-1707, 2007.

6) Valle, A., Bailey, M. J., Whiteley, A.S., Manefield, M. :
$\mathrm{N}$-acyl-L-homoserine lactones (AHLs) affect microbial community composition and function in activated sludge, Environ. Microbiol, Vol. 6, pp. 424-433, 2004.

7) Ichihashi, O., Satoh, H., Mino, T. : Sludge-sludge interaction in the enhanced biological phosphorus removal process, Water Sci. Technol., Vol. 53, pp. 1-6, 2006.

8) Satoh, H., Ogawa, Y., Mino, T. : Effect of activated sludge extract on microbial population in activated sludge screened by incubation on microplates, Environ. Eng. Res., Vol. 46, pp. 503-510, 2009.

9) Komsta L. : Package 'outliers', R-project, 2014. (http://http://cran.r-project.org/web/packages/outliers/outlie rs.pdf, accessed Aug. 20, 2014)

10) R Core Team : R: A language and environment for statistical computing, R Foundation for Statistical Computing, Vienna, Austria, 2014.

11) Satoh H., Onuki M., Mino T. : Development of a novel DNA extraction method based on sonication followed by dilution for microbial community analysis of activated sludge sample, Environ. Eng. Res., Vol. 45, pp. 225-232, 2008.

12) Lane, D. J. : 16S/23S rRNA sequencing. In: Stackebrandt E, Goodfellow M, eds. Nucleic acid techniques in bacterial systematics. Chichester, John Wiley \& Sons, pp. 115-175, 1991.

13) Duarte, G. F., Rosado, A. S., Seldin, L., Keijzer-Wolters, A. C., Van Elsas, J. D. : Extraction of ribosomal RNA and genomic DNA from soil for studying the diversity of the indigenous bacterial community, J. Microbiol. Meth., Vol. 32, pp. 21-29, 1998.

14) Selenska-Pobell, S. : Direct and simultaneous extraction of DNA and RNA from soil. in: Molecular Microbial Ecology Manual, (Eds.) A. L. Akkermans, J. Elsas, F. Bruijn, Springer Netherlands, pp. 131-147, 1995.

15) Felske, A., Rheims, H., Wolterink, A., Stackebrandt, E., Akkermans, A. D. L. : Ribosome analysis reveals prominent activity of an uncultured member of the class Actinobacteria in grassland soils. Microbiology, Vol. 143, pp. 2983-2989, 1997.

16) Griffiths, R. I., Whiteley, A. S., O'Donnell, A. G., Bailey, M. J. : Rapid method for coextraction of DNA and RNA from natural environments for analysis of ribosomal DNAand rRNA-based microbial community composition, Appl. Environ Microbiol., Vol. 66, pp. 5488-5491, 2000.

(Received May 23, 2014) 